\title{
Cameroonian Urban Floodwater Retaliations on Human Activity and Infrastructural Developments in Channel Flood Ways of Kumba
}

\author{
Zephania N. Fogwe1, Emilia Ngum Asue ${ }^{2}$ \\ ${ }^{1}$ Laboratory of Environment, Hazards and Sustainable Development, Department of Geography, Faculty of \\ Letters and Social Sciences, University of Douala, Douala, Cameroon \\ ${ }^{2}$ Department of Geography, Higher Teachers Training College, The University of Bamenda, Bambili, Cameroon \\ Email:nfogwez@yahoo.co.uk, asue@yahoo.mail
}

Received 23 December 2015; accepted 25 March 2016; published 28 March 2016

Copyright (C) 2016 by authors and Scientific Research Publishing Inc.

This work is licensed under the Creative Commons Attribution International License (CC BY).

http://creativecommons.org/licenses/by/4.0/

(c) (i) Open Access

\section{Abstract}

In Cameroonian cities, floods from solid pollutant barriers constitute environmental hazards of new distinct dimension, nature and characteristics. This study examines geographical settings provoking floods in cities and the way it affects the population. It suggests appropriate policy mitigation options. Primary and secondary data collected through fieldwork and documentary sources were treated. Findings show that national and local rules and legislation are weakly applied exposing urban natural floodway to varied forms of human colonisation activities. These urban stream flood ways that ought to be downstream water evacuation role players reversed into inhabited neighbourhoods of diverted water. Human activities and infrastructural urban inputs that unconsciously imposed directional dictates unto urban stream flow have become self-made victims of wicked egocentrism over urban stream channels. As nature is permanently in a state of dynamic re-equilibration the urban stream waters have in retaliation taught its trouble givers a disproportionately unequal negative response in enormous fatalities for the humans who dare to resist its floods and abandonment for those who have been repeatedly humbled by its floods. The response from this no man's land of aborted human conquest requires comprehensive and multidimensional environmental management in stream-bordered urban built.

\section{Keywords}

Garbage, Floods, Kumba, Population, Stream Channel 


\section{Introduction}

When discharge exceeds stream channel capacity to contain water the obvious is flood. Such floods result from high precipitation as well as barrier effect due to channel sediments or solid waste. Floods present environmental and social consequences in urban areas through economic loss, misery and deaths in direct function of population density and crowdedness of human activities on flood plains and contamination (Fogwe \& Fombutio, 2010). Stream and riverbanks constituted settlement start-off points in many cities pushing most urban dwellers into the logic of "not in my backyard" dump sites to the detriment of stream channels.

Human activities and colonisation of flood plains increase both flood severity and frequency (Fogwe \& Lambi, 2001; Dias, 2013) and cognisant of the fact that these areas are increasingly vegetable cultivation (Nkwenmoh, 2015) it remarked that since the start of the $21^{\text {st }}$ century rainy season floods gravely affect urban tropical urban centres. In Cameroon, such phenomenon is widely reported in recent urban hazard studies for coastal towns like Limbe, Tiko, Douala (Mainet, 1978; Fogwe, 2005, 2008, 2009; Dzalla Ngangue, 2013) and Kribi. Inland towns have also had flood such as those of Yaounde (Lambi \& Fogwe, 2001), Kumba and Bamenda (Azeh, 2011; Ndakwa, 2011). Kumba, that is our focus in this study, like other inland towns witnessed repeated high impact stream channel floods because their narrowness, numerous tributaries and in water channel solid waste.

Urban population dispose solid waste at random in towns where only little government effort can possibly remove the garbage from such build up points that are urban no man's lands as bridges and stream banks. Such areas have emerged to gain significance in Kumba at Meta Quarter, Cow Fence, Apostolic and Preventive Street bridges that not only barriers but toxifies urban streams exposing the population in July, August and September as far as urban peripheries in Kake I and II, and Malende as observed in Lagos (Adelekan, 2010). Within the town this is most observed in Malabo, Mbanya, Saker C.B.C Field, Cameroon Street, Ibo, Ludo, SONAC Street, parts of Buea Road, Cow Fence, and Kosala II and III (Pulitin quarter).

This study observed that flood fatalities in Kumba vary with site and time and this wreaks considerable toll on property, settlement, and farmlands since some fifty years ago. In response, counter flood structural measures have limited degree of success from the construction of high verandas, walls, houses on raised plinths, filling of foundations and digging of gutters. This study assesses how human provocations on stream channels become floodwater attacks on human elements that obstructed them. The hypothesis is that human actions on the Kumba flood plain environment provoke a natural response that seeks to establish lost balance.

\section{Methodology}

\subsection{Choice of Case Study and Sampled Areas}

The choice of Kumba is due to its inland near coastal position. Kumba sited in the far shadow of the Mount Cameroon $(4100 \mathrm{~m})$. It is the economic capital of the South West Region in Meme Division (with three

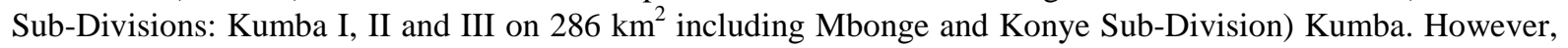
on a level topography, it has few hills at Station, New Quarters, Hausa Quarters, as well as downhill quarters in Mbonge Road neighbourhoods like Makata, Nkamulukum, Kosala, Malende, Malabo and Saker C.B.C Field being flood prone.

The Kumba Water (Kumba River) cuts across this plain unleashing floods wherever its channel has been clandestinely tampered like Malabo and Nsieh quarters after the confluence of tributary streams like Mambungise, Mbanga Water or Bombele and Fiseme Water extended to Apostolic Church Quarter, New Quarters, SONAC Street, Ludo Street, Ibo Quarters, Kake II Bokoko, Malende and Mokonje. Malabo (Nsieh Quarters) and Saker C.B.C Field are marshy with a near surface water table in Alaska Street and parts of Kumba-Mbeng. The volcanic Mbo-Barombi Lake discharges stream water through Nkamlikum, Lawyer Enow Street offering the Kumba population countless stream and bridge waste dumpsites that hinder free flow of water leading to floods.

Kumba has rains in July, August, and September and early October (C.D.C Mokonje) with rainfall ranging between 1800 to 2200 mm. Though Kumba City Council by Operation Green City planted some trees subsistence farming of food crops in the town is recurrent on the alluvial yellowish red lateritic and sandy soil to feed its close to 390,000 inhabitants.

This study area has five zones. Zone I is Alaska Street, Buea Road quarter, Kumba-Mbeng, Cattle Marbet Street or Cow Fence and Bonakama. Zone II is Kosala I, II, and III). Zone III is Ntoko Street, Apostolic Church and Meta quarters. Zone IV is Cameroon Street, Malabo or Nsieh quarter and Mbo Street). Zone V is Kake II 
Bokoko, Ludo Street, SONAC Street and Ibo quarter. This division of the study area was according to field surveyed possible causality-effect relationship between human activities and flood.

\subsection{Data Collection}

Primary data were collected through field observation and monitoring, questionnaire administration and individual and group interviews with municipal authorities and group, and 5\% of the target population those living within the affected zones. Focused group discussions and interviews were undertaken. Secondary data obtained from the Delegation of Urban Development and Housing and Delegation of State Property and Land Tenure, Delegation of Urban Development and Housing, Government Delegate to the Kumba City Council and Regional Service for Meteorology for the South West. The data were treated using descriptive and the inferential statistical techniques.

\section{Results and Discussion}

\subsection{A Flood Setting Characteristic Urban Mileiu}

Kumba River and its tributaries sourcing from the forest harbouring Lake Barombi-Mbo (Figure 1) drain Kumba.

The river flows through central town while its floods affect downstream Meta quarter to Cameroon Street (Below Preventive), behind the Amusement Park, Apostolic Church, Malabo quarter, SONAC Street, Ludo Street and Cattle Marbet Street or Cow Fence. Other affected areas are Saker CBC School and Alaska Street as the channel breadth narrowed to an average $2.3 \mathrm{~m}$. This flood has varied consequences on the population (Table 1) which raises the reality of flood hazard perception in terms of causes and responsibility elsewhere (Molenaar \& Santen, 2006) and in Cameroon (Fogwe, 2015).

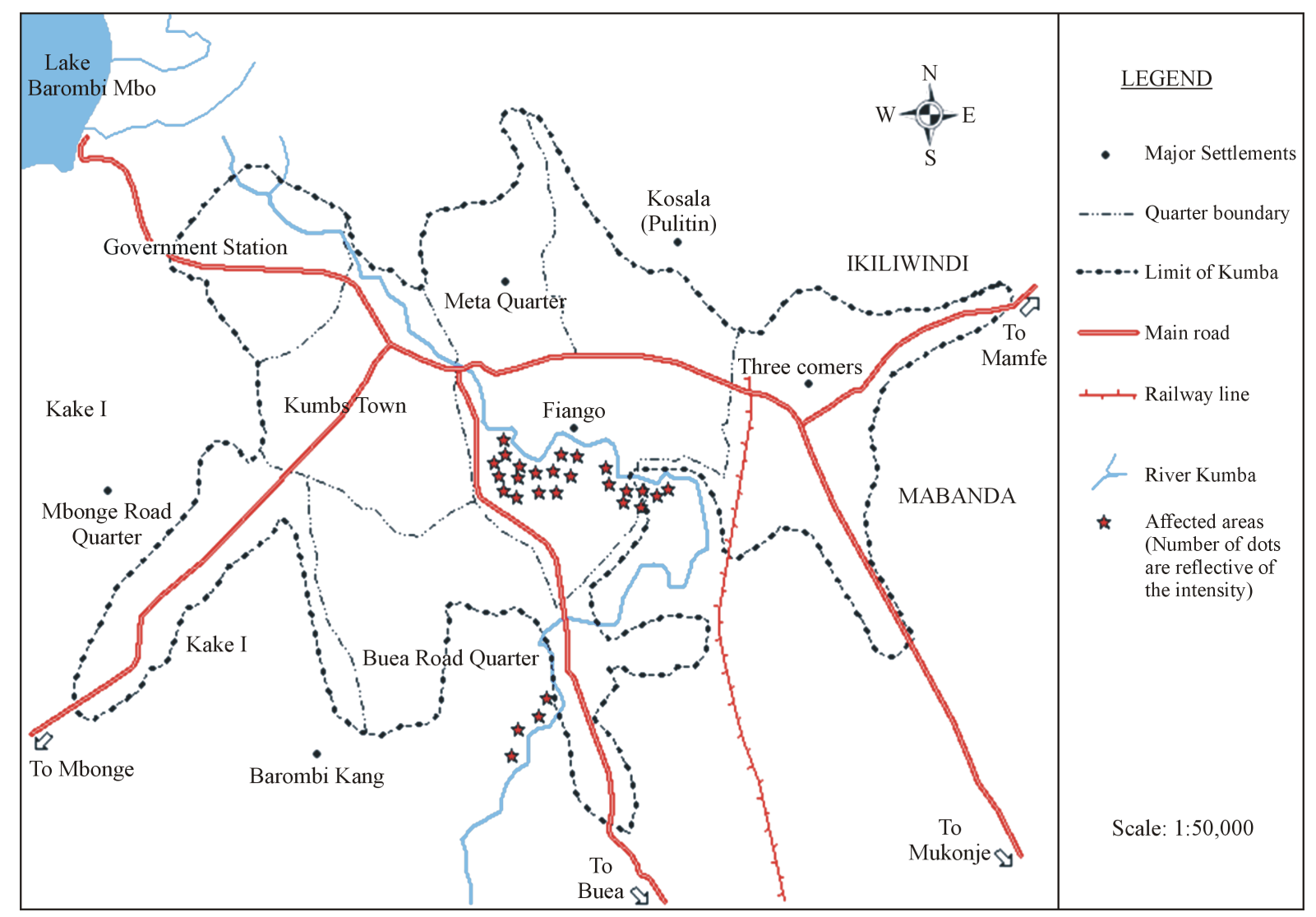

Figure 1. Kumba river and flood prone areas. Source: Adapted from Kumba City Council, (2013). 
Inadequate waste removal is a major trigger considering that only two garbage collection vehicles do waste removal. This removal is on the first Thursdays of the month. The removal sometimes stays for five to six months and so garbage heaps grow and spill into Kumba River. This stream garbage loading is aggravated by unorthodox household garbage disposal and management systems by urban dwellers (Table 2).

The bulk of waste in Kumba is either burnt (38\%) or dumped into streams (34\%) while the other forms still find their way into streams following heavy rain (Figure 2).

Kumba has a Cameroon type of equatorial climate characterised long duration and high intensity storms in August and September. Consequently, accumulation of silt reduces the channel size of Kumba River and Mabungise stream. In most channels are sturdily growing channel weeds constricting stream channels to 2 to $3 \mathrm{~m}$ wide only in several places (Figure 3).

Such obstructions were observed on the field to initiate channel water diversions as a function of the channel path (curvilinear or rectilinear) and whether obstructing material is solid (woody or garbage) or depositional (clayey or sandy). In Malabo Quarter and Saker C.B.C School Field where the water table is permanently, less than $2 \mathrm{~m}$ of the just any prolonged rains invite floods. Such flood occurred in December 2011 in Malabo Quarter, Cattle Market Street (Cow Fence) and Cameroon Street (Below Preventive).

Tarred streets along Buea Road Quarter, Commercial Avenue resulted in flash floods in Ibo Quarter, Meta Quarter, SONAC and Mbo Street. Gutter and stream discarded garbage in Kumba Market, Amusement Park and Commercial Avenue caused clogging such that water overflowed and inundated nearby land surfaces. Also, some traders contemptuously drop waste into nearby gutters thereby reducing their carrying capacity and depriving them of their original water evacuation function.

Table 1. Flood problem perception caused by Kumba River.

\begin{tabular}{|c|c|c|c|c|c|c|c|c|c|c|c|c|}
\hline \multirow{3}{*}{ Type } & \multicolumn{10}{|c|}{ Study zone } & \multirow{2}{*}{\multicolumn{2}{|c|}{ Total }} \\
\hline & \multicolumn{2}{|c|}{ I } & \multicolumn{2}{|c|}{ II } & \multicolumn{2}{|c|}{ III } & \multicolumn{2}{|c|}{ IV } & \multicolumn{2}{|c|}{$\mathrm{V}$} & & \\
\hline & $\mathrm{N}^{\circ}$ & $\%$ & $\mathrm{~N}^{\circ}$ & $\%$ & $\mathrm{~N}^{\circ}$ & $\%$ & $\mathrm{~N}^{\circ}$ & $\%$ & $\mathrm{~N}^{\circ}$ & $\%$ & $\mathrm{~N}^{\circ}$ & $\%$ \\
\hline Dirty water & 7 & 17 & 3 & 6 & 2 & 4 & 1 & 2 & 3 & 6 & 16 & 30 \\
\hline Drowning of children & 0 & 0 & 1 & 2 & 1 & 2 & 1 & 2 & 2 & 4 & 5 & 12 \\
\hline Drowning of animals & 0 & 0 & 0 & 0 & 0 & 0 & 0 & 0 & 1 & 2 & 1 & 2 \\
\hline Mosquito breading & 4 & 8 & 4 & 8 & 2 & 4 & 2 & 4 & 6 & 12 & 18 & 36 \\
\hline Flood water & 0 & 0 & 0 & 0 & 0 & 0 & 1 & 2 & 8 & 16 & 9 & 18 \\
\hline Erosion of banks & 1 & 2 & 0 & 0 & 0 & 0 & 0 & 0 & 0 & 0 & 1 & 2 \\
\hline Total & 12 & 24 & 8 & 16 & 5 & 10 & 5 & 10 & 20 & 40 & 50 & 100 \\
\hline
\end{tabular}

Source: Fieldwork, 2014.

Table 2. Poor waste management by Kumba city dwellers.

\begin{tabular}{|c|c|c|c|c|c|c|c|c|c|c|c|c|}
\hline \multirow{3}{*}{ Zones } & \multirow{2}{*}{\multicolumn{2}{|c|}{ Burnt }} & \multicolumn{6}{|c|}{ Clandestine and irregular dumping into } & \multirow{2}{*}{\multicolumn{2}{|c|}{ Others }} & \multirow{2}{*}{\multicolumn{2}{|c|}{ Total }} \\
\hline & & & \multicolumn{2}{|c|}{ Farms } & \multicolumn{2}{|c|}{ Roadside gutters } & \multicolumn{2}{|c|}{ Streams } & & & & \\
\hline & $\mathrm{N}^{\mathrm{o}}$ & $\%$ & $\mathrm{~N}^{\mathrm{o}}$ & $\%$ & $\mathrm{~N}^{\mathrm{o}}$ & $\%$ & $\mathrm{~N}^{\mathrm{o}}$ & $\%$ & $\mathrm{~N}^{\mathrm{o}}$ & $\%$ & $\mathrm{~N}^{\mathrm{o}}$ & $\%$ \\
\hline Zone I & 4 & 8 & 2 & 4 & 1 & 2 & 3 & 6 & 1 & 2 & 11 & 22 \\
\hline Zone II & 1 & 2 & 1 & 2 & 1 & 2 & 5 & 10 & 0 & 0 & 8 & 16 \\
\hline Zone III & 2 & 4 & 0 & 0 & 0 & 0 & 3 & 6 & 1 & 2 & 6 & 12 \\
\hline Zone IV & 2 & 4 & 0 & 0 & 2 & 4 & 0 & 0 & 0 & 0 & 4 & 8 \\
\hline Zone V & 10 & 20 & 5 & 10 & 0 & 0 & 6 & 12 & 0 & 0 & 21 & 42 \\
\hline Total & 19 & 38 & 8 & 16 & 4 & 8 & 17 & 34 & 2 & 4 & 50 & 100 \\
\hline
\end{tabular}

Source: Fieldwork, 2014. 

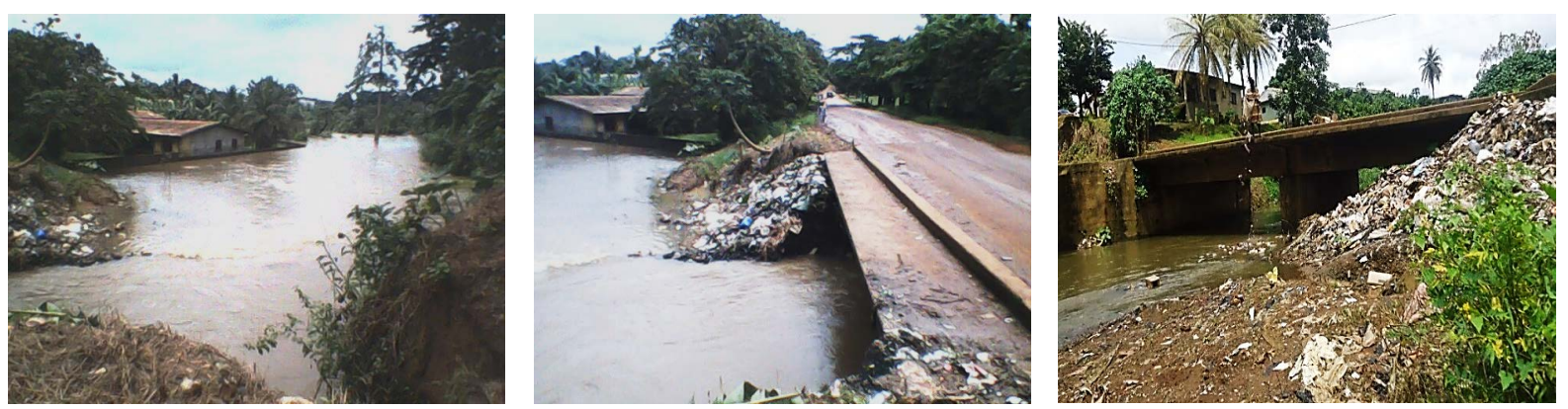

Figure 2. Garbage dumpsites colonisation along Kumba River. Source: Fieldwork, 2014.

Silt invasion of the channels of Kumba River

Tree trunk-damming effect and channel modification effect
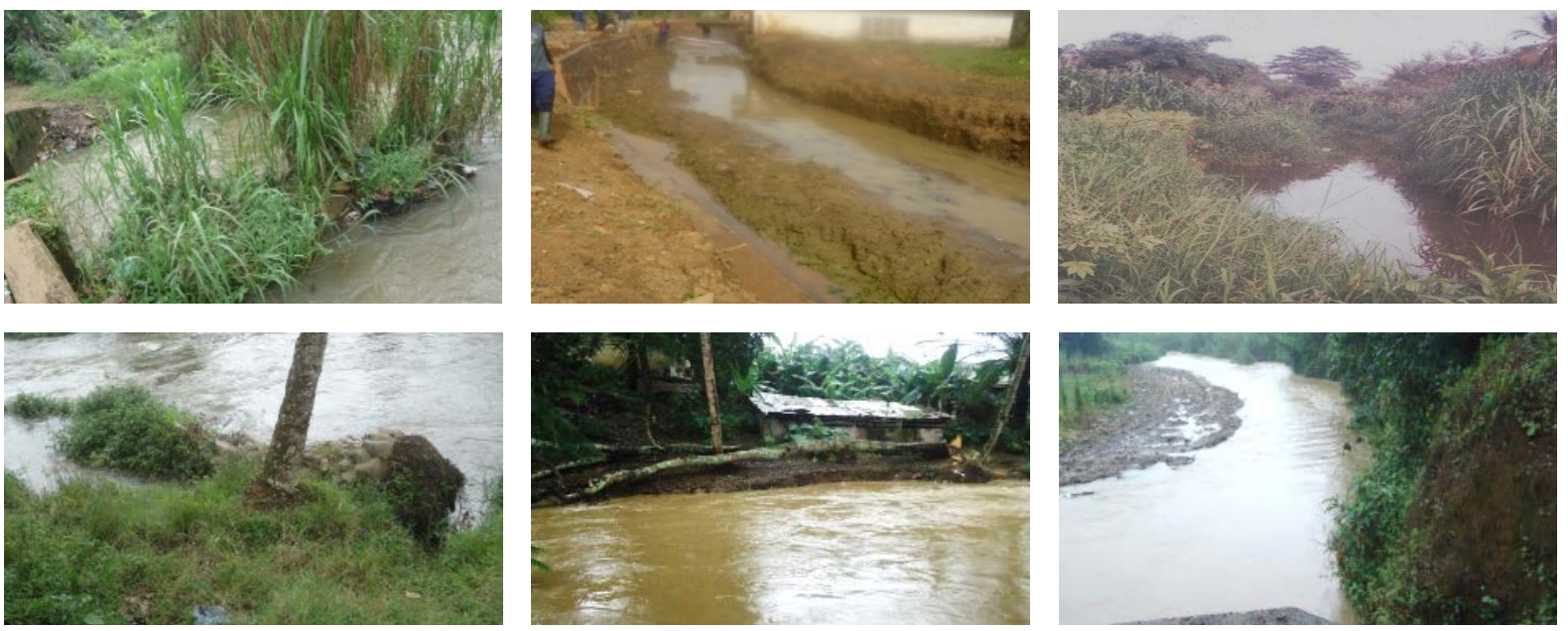

Figure 3. Middle and lateral channel triggers of water diversion. Source: Fieldwork, 2014.

Population installations and domineering strategies of flood prone land, supposed to be left $15 \mathrm{~m}$ free from human occupation to permit water flow, was observed to be particularly chaotic. Such is State land should be totally inedificandi yet are colonised in different ways with human installations in most areas being less than 10 m away from water courses (Table 3). This is because they perceive their risk to flooding differently.

Some $60 \%$ of houses along Kumba River are within $30 \mathrm{~m}$ from the banks of the river, while only $40 \%$ are 30 $\mathrm{m}$ away. Buildings within the river channel obstructs water flow which in return floods them in quarters like Malabo, Ibo, Mbo Street, Kumba-Mbeng and SONAC Street that align Kumba Water and Mabungise streams (Figure 4).

The population has continued to erect natural and artificial levees and renew with futile attempts at channel modification such as dredging to make them deeper, wider and even construct raised plinths (Figure 5) but the strategies have failed colossally as observed before in Douala (Fogwe \& Lambi, 2001; Munji et al., 2013).

Fieldwork permitted us observe a phenomenon in Zone $\mathrm{V}$ consisting of raising house foundation as per the highest to the highest flood magnitude. Owners reclaim their plots by filling foundations above surrounding ground levels. This deviates flooding to unraised plots with lower foundations. As such would in turn also raise theirs in the end, there is a generalised failure at such microscale actions (Fogwe, 2005).

The Town Planning as well as the Hygiene and Sanitation Department of the Kumba Council must approve Damp Prove Cost foundation for wetland. Most people ignore this urbanization code preventing construction within 10 meters from a watercourse in Kosala I, II, and III where surface water tables cause wells to spill into low-lying parts of Saker CBC School Field.

There is a dearth of City Council pre-emptive counter flood governance, when considered in terms of technical and institutional goals that are inexistent. The "stich in time saves nine" age-old paradigm of civilised governance gives that give pre-eminence to preventive rather than curative operationalization of human space and 
Table 3. Infrastructural implantation on flood territory in Kumba.

\begin{tabular}{|c|c|c|c|c|c|c|c|c|c|c|c|c|}
\hline \multirow{3}{*}{$\begin{array}{l}\text { Distance from } \\
\text { streams and } \\
\text { rivers }\end{array}$} & \multicolumn{10}{|c|}{ Zone } & \multirow{2}{*}{\multicolumn{2}{|c|}{ Total }} \\
\hline & \multicolumn{2}{|c|}{ I } & \multicolumn{2}{|c|}{ II } & \multicolumn{2}{|c|}{ III } & \multicolumn{2}{|c|}{ IV } & \multicolumn{2}{|c|}{ V } & & \\
\hline & $\mathrm{N}^{0}$ & $\%$ & $\mathrm{~N}^{0}$ & $\%$ & $\mathrm{~N}^{\circ}$ & $\%$ & $\mathrm{~N}^{0}$ & $\%$ & $\mathrm{~N}^{0}$ & $\%$ & $\mathrm{~N}^{\mathrm{o}}$ & $\%$ \\
\hline More than $30 \mathrm{~m}$ & 5 & 10 & 3 & 6 & 3 & 6 & 2 & 4 & 7 & 14 & 20 & 40 \\
\hline Less than $30 \mathrm{~m}$ & 7 & 14 & 5 & 10 & 2 & 4 & 2 & 4 & 14 & 28 & 30 & 60 \\
\hline Total & 12 & 24 & 8 & 16 & 5 & 10 & 4 & 8 & 21 & 42 & 50 & 100 \\
\hline
\end{tabular}

Source: Fieldwork, 2014.
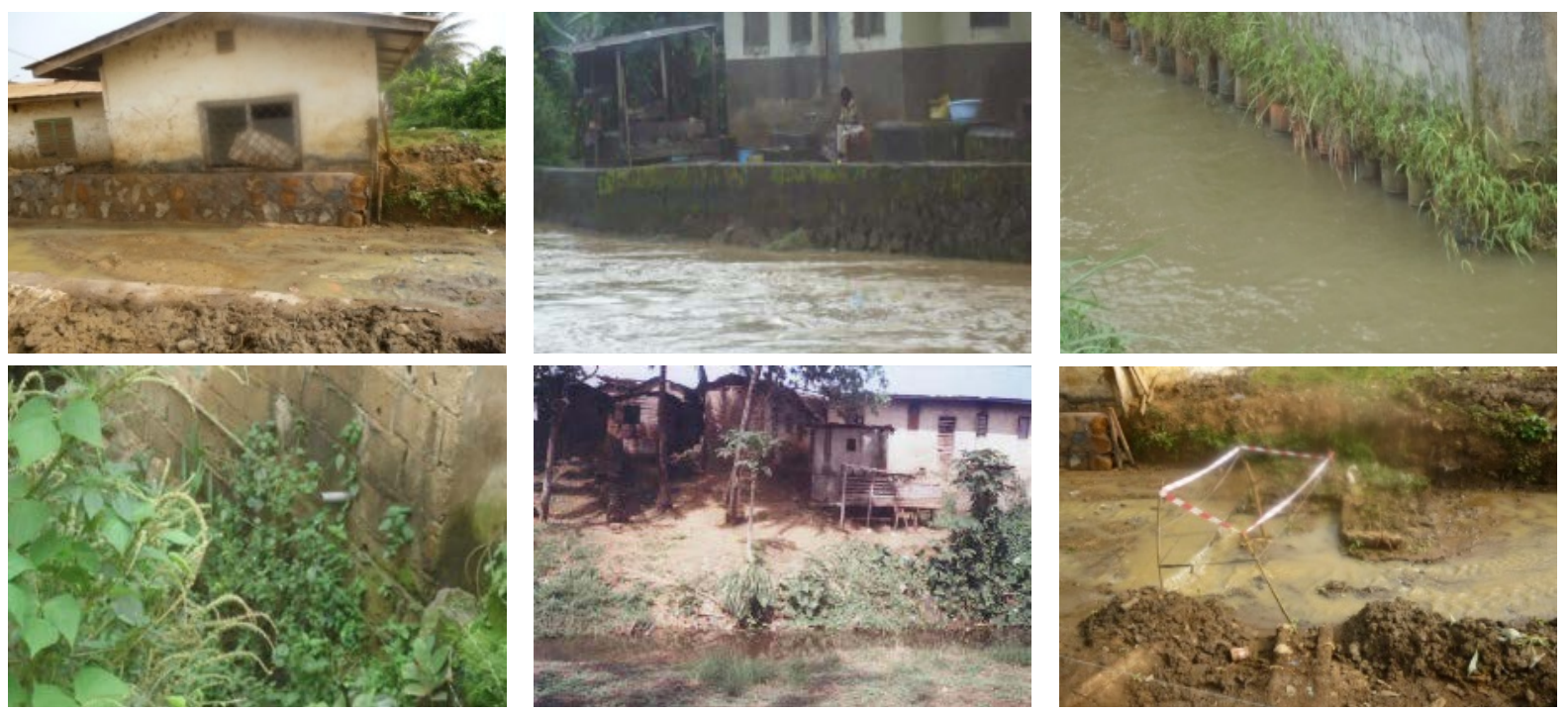

Figure 4. Constructions on Mabungise stream and Kumba Water channel banks. Source: Fieldwork, January 2014.

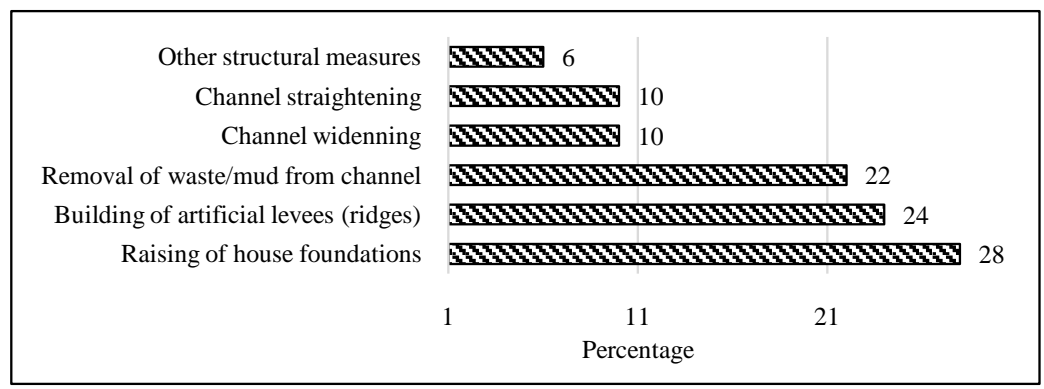

Figure 5. Stakeholder flood adaptation strategies in Kumba.

resource management is a none event in Kumba. Personal interview with the Project Manager, Kumba City Council, established that the Council lacks a specialized Department devoted to such environmental issues like urban floods. Stream and river riverine population remains largely uneducated of the ramification and who to fall to in case of flood fatality (Table 4).

Three-quarter of the population of Kumba is ignorant of flood event assistance and education because the City Council has hardly considered this waste triggered flood problem as a priority. This weakens the Council's flood management through survey or monitoring and the population continues to indulge in acts that increase the flood events.

\subsection{Human Activities of Urban Water Channel Stuffing with Solid Waste Objects}

There is waste build-up at rate that is greater than disposal. The City of Kumba generates about 250,000 tons of 
Table 4. Knowledge of flood hazard responsibility in Kumba.

\begin{tabular}{|c|c|c|c|c|c|c|c|c|c|c|c|c|}
\hline \multirow{3}{*}{ Responsibility } & \multicolumn{10}{|c|}{ Zone } & \multirow{2}{*}{\multicolumn{2}{|c|}{ Total }} \\
\hline & \multicolumn{2}{|c|}{ I } & \multicolumn{2}{|c|}{ II } & \multicolumn{2}{|c|}{ III } & \multicolumn{2}{|c|}{ IV } & \multicolumn{2}{|c|}{$\mathrm{V}$} & & \\
\hline & $\mathrm{N}^{\mathrm{o}}$ & $\%$ & $\mathrm{~N}^{\mathrm{o}}$ & $\%$ & $\mathrm{~N}^{\mathrm{o}}$ & $\%$ & $\mathrm{~N}^{\mathrm{o}}$ & $\%$ & $\mathrm{~N}^{\mathrm{o}}$ & $\%$ & $\mathrm{~N}^{\mathrm{o}}$ & $\%$ \\
\hline Nobody & 8 & 16 & 6 & 12 & 4 & 8 & 2 & 4 & 16 & 32 & 36 & 72 \\
\hline Kumba Council & 1 & 2 & 1 & 2 & 2 & 4 & 0 & 0 & 0 & 0 & 4 & 8 \\
\hline Church & 0 & 0 & 1 & 2 & 0 & 0 & 0 & 0 & 0 & 0 & 1 & 2 \\
\hline NGOs & 0 & 0 & 0 & 0 & 0 & 0 & 0 & 0 & 0 & 0 & 0 & 0 \\
\hline Friends & 2 & 4 & 0 & 0 & 0 & 0 & 2 & 4 & 5 & 10 & 9 & 18 \\
\hline Total & 11 & 22 & 8 & 16 & 6 & 12 & 4 & 8 & 21 & 42 & 50 & 100 \\
\hline
\end{tabular}

Source: Fieldwork, 2014.

refuse annually yet only 100,000 tons is removed by garbage vans (Kumba Urban Council Journal, 2002) because refuse generated per household daily ranges from 5 to 20 litters (Table 5).

Some significant quantity of refuse or waste is generated daily being 5 litters (projected to 648 tons annually). The unremoved garbage is either gets into roadside gutters or streams. The waste clogs underbridge passage ways (Figure 6) and constricts the water access way provoking the channel-damming effect as identified in Douala (Fogwe \& Tchotsoua, 2007).

Such uncollected garbage produces effective damming to channel water despite the in situ burning and warning billboards of the Kumba City Council leading to the occurrence of floods at the different bridge upstream points such as Meta Quarter, Cameroon Street, Cameroon Street and Malaba bridge points (Kumba Urban Council, 1996).

\subsection{Urban Floodplain Population: Victims of Stream Channel Victimisation Deeds}

Kumba urban population has variously affected stream channels so the water has responded to nature's spatial and time re-equilibration. Fieldwork assessed this adage phenomenon of how "the hunter became hunted" of flood scenario in Cameroon towns using twelve sample sites in Kumba. For purpose of qualitative analyses, five zones (based on the visual similitude between flood reactions on humans) identified were:

- Zone I (Buea Road Quarter, Kumba-Mbeng, Cattle Marbet Street or Cow Fence and Bonakama);

- Zone II (Kosala 1, 2 and 3);

- Zone III (Ntoko Street, Apostolic Church, Meta Quarters);

- Zone IV (Cameroon Street, Malabo or Nsieh quarter and Mbo Street);

- Zone V A (Kake 2 Bokoko); and Zone V B (Ludo Street, SONAC Street and Ibo Quarters).

Zone I: Faces interruptions of mobility due to the low-lying nature of the area and malaria epidemic because $60 \%$ of houses are constructed at less than $30 \mathrm{~m}$ from the stream banks and mindful of the flat topography, and characteristic rainfall access ways and roads to schools and homes are often swallowed up by flood waters. The hardest hit population becomes business people, pupils and students of primary, secondary and university establishments who must remain indoors until water level subsides as attested by $90 \%$ of respondents (Table 6).

Some $44 \%$ of the victims are students whose educational performance is certainly affected. The students fall within the bulk and age group that is directly used or sent by the different households clandestinely dispose of domestic refuse that finds itself in the streams, which react to them in this way. They therefore pay the unforeseen price of unintentional urban environmental misdeed aimed at illicit transference of common responsibility. Urban floodwaters therefore reacts by flowing into neighbouring homes that had contributed to pollute the channel way. The floodwater last for weeks and becomes harbouring ground for disease-vectors (Fogwe \& Fombutio, 2010) like mosquito that spread malaria as attested by $24 \%$ to $32 \%$ of the neighbourhood population.

Zone II: The shallow water table on a plane landscape accelerates the ground water recharge resulting in marshy conditions that are muddy in the rainy season. Wells and pit toilets free their excess water so it that interconnects to constitute a platform per excellence of health risks to the population. Vehicular flow in and out of the neighbourhood is hard in the rainy season worsened by random waste dumps by residents. 
Table 5. Relative distribution of daily household waste generation in Kumba.

\begin{tabular}{|c|c|c|c|c|c|c|c|c|c|c|c|c|}
\hline \multirow{3}{*}{$\begin{array}{c}\text { Quantity } \\
\text { (litters) }\end{array}$} & \multicolumn{10}{|c|}{ Zone } & \multirow{2}{*}{\multicolumn{2}{|c|}{ Total }} \\
\hline & \multicolumn{2}{|c|}{ I } & \multicolumn{2}{|c|}{ II } & \multicolumn{2}{|c|}{ III } & \multicolumn{2}{|c|}{ IV } & \multicolumn{2}{|c|}{$\mathrm{V}$} & & \\
\hline & $\mathrm{N}^{0}$ & $\%$ & $\mathrm{~N}^{\mathrm{o}}$ & $\%$ & $\mathrm{~N}^{\mathrm{o}}$ & $\%$ & $\mathrm{~N}^{\mathrm{o}}$ & $\%$ & $\mathrm{~N}^{\mathrm{o}}$ & $\%$ & $\mathrm{~N}^{\circ}$ & $\%$ \\
\hline 5 & 7 & 14 & 2 & 4 & 4 & 8 & 1 & 2 & 13 & 26 & 27 & 54 \\
\hline 10 & 3 & 6 & 4 & 8 & 1 & 2 & 2 & 4 & 4 & 8 & 14 & 28 \\
\hline 15 & 0 & 0 & 2 & 4 & 0 & 0 & 1 & 2 & 1 & 2 & 4 & 8 \\
\hline$>20$ & 2 & 4 & 0 & 0 & 0 & 0 & 0 & 0 & 3 & 6 & 5 & 10 \\
\hline Total & 12 & 24 & 8 & 16 & 5 & 10 & 4 & 8 & 21 & 42 & 50 & 100 \\
\hline
\end{tabular}

Source: Fieldwork, 2014.

Table 6. Acknowledgment of floodwater as impediment to mobility in Kumba.

\begin{tabular}{|c|c|c|c|c|c|c|c|c|c|c|c|c|}
\hline \multirow{3}{*}{$\begin{array}{l}\text { Respondent } \\
\text { profession }\end{array}$} & \multicolumn{10}{|c|}{ Zone } & \multirow{2}{*}{\multicolumn{2}{|c|}{ Total }} \\
\hline & \multicolumn{2}{|c|}{ I } & \multicolumn{2}{|c|}{ II } & \multicolumn{2}{|c|}{ III } & \multicolumn{2}{|c|}{ IV } & \multicolumn{2}{|c|}{ V } & & \\
\hline & $\mathrm{N}^{0}$ & $\%$ & $\mathrm{~N}^{\circ}$ & $\%$ & $\mathrm{~N}^{\mathrm{o}}$ & $\%$ & $\mathrm{~N}^{\circ}$ & $\%$ & $\mathrm{~N}^{\mathrm{o}}$ & $\%$ & $\mathrm{~N}^{\mathrm{o}}$ & $\%$ \\
\hline Farming & 1 & 2 & 0 & 0 & 2 & 4 & 0 & 0 & 4 & 8 & 07 & 14 \\
\hline Civil servant & 3 & 6 & 0 & 0 & 0 & 0 & 1 & 2 & 2 & 4 & 06 & 12 \\
\hline Trading & 0 & 0 & 2 & 4 & 1 & 2 & 0 & 0 & 3 & 6 & 06 & 12 \\
\hline Driving & 0 & 0 & 0 & 0 & 0 & 0 & 0 & 0 & 1 & 2 & 01 & 2 \\
\hline Students & 8 & 16 & 3 & 6 & 0 & 0 & 1 & 2 & 10 & 20 & 22 & 44 \\
\hline Medical & 1 & 2 & 2 & 4 & 1 & 2 & 0 & 0 & 0 & 0 & 04 & 08 \\
\hline Others & 0 & 0 & 0 & 0 & 1 & 2 & 2 & 4 & 1 & 2 & 04 & 08 \\
\hline Total & 13 & 26 & 07 & 14 & 05 & 10 & 4 & 8 & 21 & 42 & 50 & 100 \\
\hline
\end{tabular}

Source: Fieldwork, 2014.
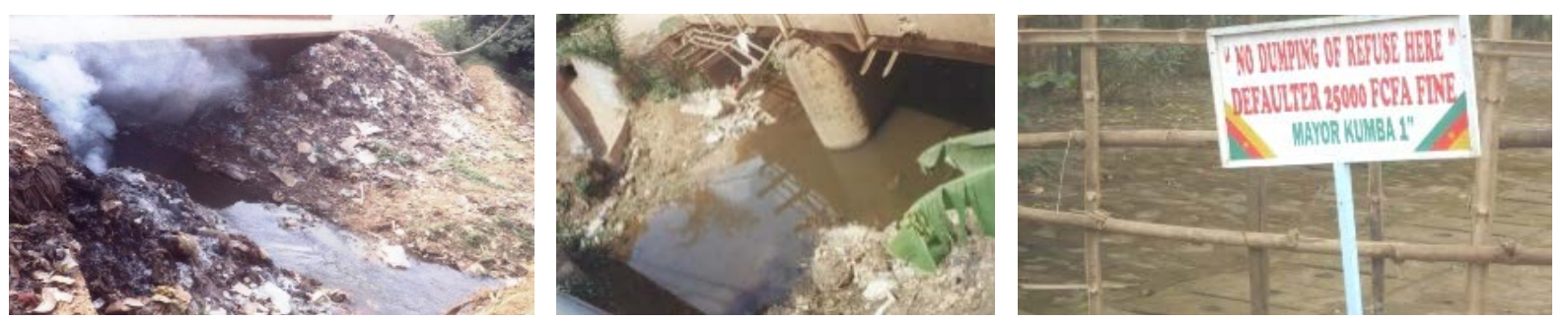

Figure 6. Underbridge waste damming in River channel. Source: Fieldwork, March 2014.

Zone III: Two main streams flood these localities being Mambungise and Kumba Water that does not spare houses located at close proximity to the stream. Focused group discussion during fieldwork with 12 homes acknowledged destroyed by floodwaters in five flood occurrences in the last nine years. Tangible losses were countless furniture and dresses. Human casualty recorded was a bike rider. Personal interview (during fieldwork) with Victor Schwoiser-attest to the greater pollution (85\%) level of Kumba Water. The Kumba Water receives large quantities of plastics and rags and other objects that have reduced visibility through the water to only $1 \mathrm{~m}$ compared to $4 \mathrm{~m}$ in the 1970s. Along the Mambungise stream, more than 20 homes are at pollution risk. Wells are contaminated by pit latrine water and faeces washed out of such toilets. The technical team dredging the Mambungise (HIMO Project) attests having killed snakes like vipers, cobras, black snakes and others since work started in November 2013. The stream odour produced by the faeces, garden waste and pigsties mixed in mud is nauseating. 
Zone IV: There is traffic disruption as Kumba River floodwater cover the bridge to a height of about 1 to 1.5 $\mathrm{m}$ most times. Two cases of death have been recorded not withstanding property damage. At the extreme of the flood water revenge on population premises, people surrender and flee for their dear lives leaving behind infrastructure that they initially provoked the cannel ways with such as houses and even colossal investments as whole school premises like that of the National Progressive College Kumba and Faith Comprehensive High School (Figure 7).

The flood waters gladly and forcefully become its new occupants, degrading and destroying what it can like fences and other barriers as fast as it can (Table 7).

In Malabo quarter, the population has abandoned close to $20 \%$ of houses yet the more recalcitrant choose to construct raised plinths to avoid flooding water effects. In Mbo Street, farms and household equipment damages are high. Reptiles and other water creatures alongside repulsive toilet and sceptic tank contents spread into houses by the floodwaters. The losses comprise of both tangible and intangible items as classified by Smith and Ward (1998).

Zone V: This permanent swamp has swallowed up arable land and backyards of houses situated along the main roads as well as home gardens. Floodwaters here offer good excellent dwelling habitats for mosquitoes and reptiles like snakes. Wells fill up just as the shallow pit latrines so that their mixed contents freely circulate on the surface to pose a significant health hazard to the community. The central town floodwater losses are severe on furniture, electronics, documents, dresses and goods. Often floodwater takes about two days to recede, causing a blockage of traffic flow along these streets.

Fieldwork permitted this study to evaluate the farm returns from exploiting flood prone areas and why the population remains attached to such areas. Results reveal that it is not even very profitable to colonise and live on such channel areas (Table 8).

Almost half of the urban farmers make just between 5000 to 10,000 FCFA profit from the farming activity perhaps due to recurrent floodwater damages. This makes it not a very profitable activity and hence question, then why does the population choose such areas to live in the wake of the risks involved? From field observation, the urban poor prefer such settlements because of the affordable value of the land and high accessibility (Table 9).
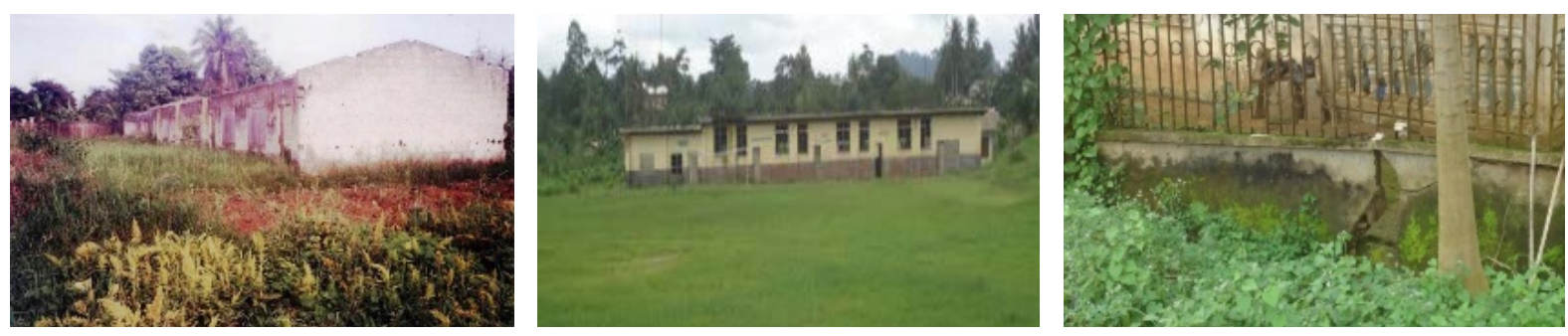

Figure 7. School buildings and damaged fences surrendered to floods in Kumba.

Table 7. Recorded floodwater losses in Kumba.

\begin{tabular}{|c|c|c|c|c|c|c|c|c|c|c|c|c|}
\hline \multirow{3}{*}{ Items } & \multicolumn{10}{|c|}{ Zone } & \multirow{2}{*}{\multicolumn{2}{|c|}{ Total }} \\
\hline & \multicolumn{2}{|c|}{ I } & \multicolumn{2}{|c|}{ II } & \multicolumn{2}{|c|}{ III } & \multicolumn{2}{|c|}{ IV } & \multicolumn{2}{|c|}{$\mathrm{V}$} & & \\
\hline & $\mathrm{N}^{\mathrm{o}}$ & $\%$ & $\mathrm{~N}^{\mathrm{o}}$ & $\%$ & $\mathrm{~N}^{\mathrm{o}}$ & $\%$ & $\mathrm{~N}^{\mathrm{o}}$ & $\%$ & $\mathrm{~N}^{\mathrm{o}}$ & $\%$ & $\mathrm{~N}^{\mathrm{o}}$ & $\%$ \\
\hline Farm crops & 5 & 10 & 1 & 2 & 2 & 4 & 1 & 2 & 10 & 20 & 19 & 38 \\
\hline Houses & 3 & 6 & 1 & 2 & 0 & 0 & 1 & 2 & 5 & 10 & 10 & 20 \\
\hline House property & 0 & 0 & 4 & 8 & 1 & 2 & 2 & 4 & 4 & 8 & 11 & 22 \\
\hline Animals & 1 & 2 & 1 & 2 & 1 & 2 & 0 & 0 & 1 & 2 & 04 & 08 \\
\hline Others & 3 & 6 & 0 & 0 & 2 & 4 & 0 & 0 & 1 & 2 & 06 & 12 \\
\hline Total & 12 & 24 & 7 & 14 & 6 & 12 & 4 & 8 & 21 & 44 & 50 & 100 \\
\hline
\end{tabular}

Source: Fieldwork, 2014. 
Table 8. Percentage profit of farming flooded areas per year.

\begin{tabular}{|c|c|c|c|c|c|c|c|c|c|c|c|c|}
\hline \multirow{3}{*}{$\begin{array}{l}\text { Profit range } \\
\text { (FCFA) }\end{array}$} & \multicolumn{10}{|c|}{ Zone } & \multirow{2}{*}{\multicolumn{2}{|c|}{ Total }} \\
\hline & \multicolumn{2}{|c|}{ I } & \multicolumn{2}{|c|}{ II } & \multicolumn{2}{|c|}{ III } & \multicolumn{2}{|c|}{ IV } & \multicolumn{2}{|c|}{ V } & & \\
\hline & $\mathrm{N}^{\circ}$ & $\%$ & $\mathrm{~N}^{0}$ & $\%$ & $\mathrm{~N}^{0}$ & $\%$ & $\mathrm{~N}^{\mathrm{o}}$ & $\%$ & $\mathrm{~N}^{\mathrm{o}}$ & $\%$ & $\mathrm{~N}^{\circ}$ & $\%$ \\
\hline $5000-10,000$ & 8 & 16 & 4 & 8 & 2 & 4 & 3 & 6 & 6 & 12 & 23 & 46 \\
\hline $15,000-20,000$ & 2 & 4 & 0 & 0 & 1 & 2 & 1 & 2 & 5 & 10 & 09 & 18 \\
\hline $25,000-30,000$ & 0 & 0 & 4 & 8 & 0 & 0 & 0 & 0 & 3 & 6 & 07 & 14 \\
\hline$>40,000$ & 2 & 4 & 0 & 0 & 2 & 4 & 0 & 0 & 7 & 14 & 11 & 22 \\
\hline Total & 12 & 24 & 8 & 16 & 5 & 10 & 4 & 8 & 21 & 42 & 50 & 100 \\
\hline
\end{tabular}

Source: Fieldwork, 2014.

Table 9. Justifications for inhabiting flood prone areas in Kumba.

\begin{tabular}{|c|c|c|c|c|c|c|c|c|c|c|c|c|}
\hline \multirow{3}{*}{$\begin{array}{c}\text { Habitation } \\
\text { Reasons }\end{array}$} & \multicolumn{10}{|c|}{ Zone } & \multirow{2}{*}{\multicolumn{2}{|c|}{ Total }} \\
\hline & \multicolumn{2}{|c|}{ I } & \multicolumn{2}{|c|}{ II } & \multicolumn{2}{|c|}{ III } & \multicolumn{2}{|c|}{ IV } & \multicolumn{2}{|c|}{$\mathrm{V}$} & & \\
\hline & $\mathrm{N}^{0}$ & $\%$ & $\mathrm{~N}^{\mathrm{o}}$ & $\%$ & $\mathrm{~N}^{\mathrm{o}}$ & $\%$ & $\mathrm{~N}^{\mathrm{o}}$ & $\%$ & $\mathrm{~N}^{0}$ & $\%$ & $\mathrm{~N}^{\mathrm{o}}$ & $\%$ \\
\hline Cheap land & 4 & 8 & 5 & 10 & 1 & 2 & 0 & 0 & 8 & 16 & 18 & 36 \\
\hline For farming & 1 & 2 & 1 & 2 & 1 & 2 & 0 & 0 & 2 & 4 & 05 & 10 \\
\hline Access to water & 1 & 2 & 0 & 0 & 1 & 2 & 1 & 2 & 0 & 0 & 03 & 06 \\
\hline High accessibility & 3 & 6 & 2 & 4 & 2 & 4 & 3 & 6 & 9 & 18 & 19 & 38 \\
\hline Others & 3 & 6 & 0 & 0 & 0 & 0 & 0 & 0 & 2 & 4 & 05 & 10 \\
\hline Total & 12 & 24 & 8 & 16 & 5 & 10 & 4 & 8 & 21 & 42 & 50 & 100 \\
\hline
\end{tabular}

Source: Fieldwork, 2014.

Some residents added that choosing such area permits them to carry out farming along the streams all year round, which assures them of a steady annual income. All use such stream water for domestic washing of items and bathing, though drinking water is bought from commercial public taps. They explained that it would be very expensive if they have to purchase all the water they use.

\section{Conclusions}

Considering the multitude of pollution and floods negative repercussions on the urban population of Kumba in tangible and intangible losses that result from human misplaced priorities, the need for lasting mitigating measures becomes an urban governance obligation. Results show that the population of Kumba has modified the hydro-geological or hydro-physiographical equilibrium of their habitat. These systems have reacted severely and risk continuing doing so in very disgusting and calamitous magnitudes.

The results also show that human containment of the water system is limited in space and time. Failed mitigation attempts and errors of the past continue to be committed. This has permitted urban flood and pollution pitfalls to be spread to individual and the whole urban community though the urban have-nots and disempowered population (that are in the majority), have been the most inflicted as noted in Ghana (Betey, 2013). Caught in this type of poverty vicious cycle, the disadvantaged urban population resorts to indigenous "isolation island" strategies against floodwaters by building high veranda walls, and embankments of waterways above normal flood levels. The City and Municipal Councils better equipped and financed in the fight against urban flood and pollution engaged in structural and engineering schemes.

The Council has attempted strict implement, the urbanization law that restricts illegal construction on wetlands or $10 \mathrm{~m}$ close to streams unless the dam prove cost plan has been authorized. The "HIMO PROJECT" (HAUTE INTENSITE DES MAIN D’OUVRES) otherwise THE LABOUR INTENSIVE project to dredge the Mambungise channel does not yield the expected results (Plate 1). 


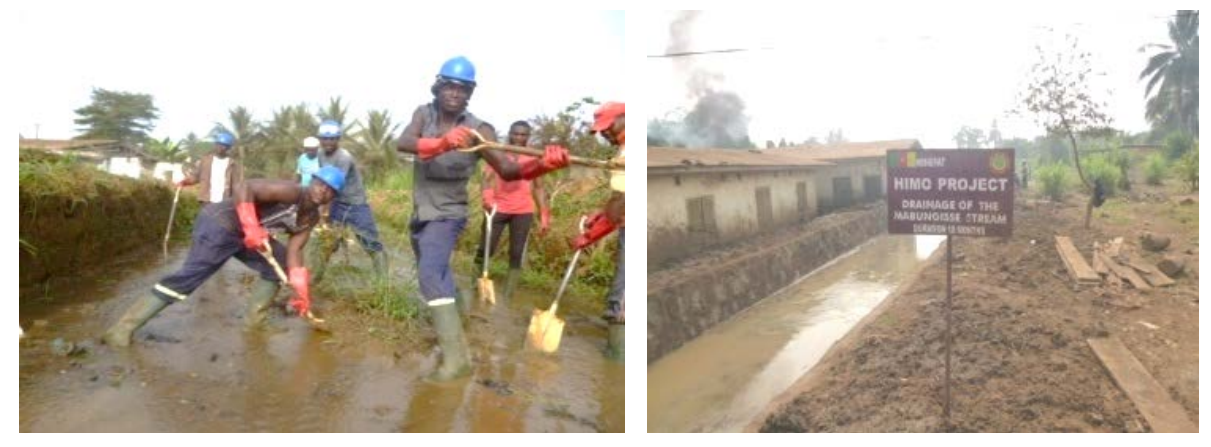

Plate 1. Labour intensive dredging project (HIMO) of stream channel in Kumba. Source: Fieldwork, January 2015.

The Hygiene and Sanitation Department of the Kumba City Council has posted warning boards at the bridge points to sensitise against refuse channelling into streams yet the phenomenon is on the rise. The refuse is at times set on fire requiring greater psycho-geographical reinforcements as noted in Douala (Fogwe \& Nkelzok, 2013).

Tackling problems of flood and pollution in the Kumba urban space cannot be completely resolved at individual levels. The way forward in this study could be an integrated or participatory approach in which all the stakeholders collaborate in countering flood and pollution problems. This would be giving meaning to sustainable urban governance and urban environmental development. Precautionary and control mechanisms of river pollution and floods in urban streams and rivers not only in Kumba but also in Cameroon as a whole strengthen and preserve the remaining ecological resources for posterity albeit what currently obtains at individual and macro levels. This means that other plausible options are needed as national and international responses to the improvement in both pollution and flood control in Cameroonian cities.

\section{References}

Adelekan, I. O. (2010). Vulnerability of Poor Urban Coastal Communities to Flooding in Lagos, Nigeria. Environment and Urbanization, 22, 433-450. http://dx.doi.org/10.1177/0956247810380141

Azeh, M. S. (2011). Vulnerability to Flood and Socio-Economic Implications in Bamenda, the North West Region of Cameroon. Unpublished DIPES II Dissertation, Higher Teacher Training College, Bambili, University of Bamenda, 99 p.

Betey Campion, B., \& Venzke, J.-F. (2013). Rainfall Variability, Floods and Adaptations of the Urban Poor to Flooding in Kumasi, Ghana. Natural Hazards, 65, 1895-1911. http://dx.doi.org/10.1007/s11069-012-0452-6

Dias, L. F. (2013). City, Climate Change and Floods. A Contribution to the Urban Resilience Study. In Klijn \& Schweckendiek (Eds.), Comprehensive Flood Risk Management. London: Taylor \& Francis Group.

Dzalla Ngangue, G. C. (2013). Mangrove de l'estuaire du Wouri: Enjeux de l'anthropisation d'un écosystème humide tropical et impacts environnementaux. Thèse de Doctorat Université de Douala, 446.

Fogwe, Z. N., \& Lambi, C. M. (2001). Combatting Inundation in Some Cameroonian Cities: An Appraisal of Indigenous Strategies. In C. M. Lambi (Ed.), Environmental Issues: Problems and Prospects (pp. 133-146). Bamenda: Unique Printers and Publisher.

Fogwe, Z. N. (2005). Urban Development and Environmental Assessment of the Douala Metropolis. Unpublished Ph.D Thesis, Department of Geography, FSMS, University of Buea, 371 p.

Fogwe, Z. N. (2008). The Cameroonian City Counter-Flood Response Strategies at the 21st Century. Journal of Applied Social Sciences, 7.

Fogwe, Z. N. (2009). Recurrent Urban Deluges and Rainfall Intensity in the Gulf of Guinea. Journal of Intra-African Studies, 2.

Fogwe, Z. N. (2015). Perception of Some Recent Flood Risks and Hazards in Cameroon in Dominique MEVA'A ABOMO

(Ed) De la faillite de la santé urbaine à la ville-santé au Cameroun regards croisés entre acteurs, pratiques, défis et enjeux, Edition Universitaires Europeennes, OmnScriptum, Saarbrucken, Deutschland, 34-49.

Fogwe, Z. N., \& Fombutio, C. N. (2010). Tropical City Milieux and Disease Infection: The Case of Douala, Cameroon. Journal of Human Ecology, 30, 123-130.

Fogwe, Z. N., \& Nkelzok, V. K. (2013). Psycho-Geographical Evaluation of the Douala City (Cameroon) Sensitisation Pro- 
gramme against Municipal Waste Dilemma. International Journal of Research in Arts and Social Sciences, 5, 204-216.

Fogwe, Z. N., \& Tchotsoua, M. (2007). Evaluation géographique de deux décennies de lutte contre les inondations dans la ville de Douala (Cameroun). Actes des JSIRAUF, Hanoi, 6-9 November 2007.

Kumba Urban Council (1996). To the Kumba City Council 2008, City of Kumba-A Photographic Presentation.

Lambi, C. M., \& Fogwe, Z. N. (2001). The February 2000 Floods in Down Town Yaoundé. In C. M. Lambi, \& E. B. Eze (Eds.), Readings in Geography (pp. 119-126). Bamenda: Unique Printers and Publisher.

Mainet, G. (1978). Les Inondations Intérieures à la Ville de Douala (67 p). Yaoundé.

Molenaar, J. W., \& Van Santen, J. C. M. (2006). Perceptions of Water in a Changing Hydrological and Ecological Context: The Case of the Logone Flood Plains in Cameroon. The Geographical Journal, 172, 331-347. http://dx.doi.org/10.1111/j.1475-4959.2006.00216.x

Munji, C. A., Bele, M. Y., Nkwatoh, A. F., Idinobac, M. E., Somorin, O. A., \& Sonwa, D. J. (2013). Vulnerability to Coastal Flooding and Response Strategies: The Case of Settlements in Cameroon Mangrove Forests. Environmental Development, 5, 54-72. http://dx.doi.org/10.1016/j.envdev.2012.10.002

Ndaka, M. A. (2011). Urban Floods: Perception of Trigger Mechanisms and Implications for Management (79 p). The Case of Bamenda, Unpublished DIPES II Dissertation, Bambili: Higher Teacher Training College, University of Bamenda.

Nkwenmoh, C. A. (2015). Surviving through Horticulture in the Yaounde Metropolis, Cameroon. African Journal of Social Sciences, 6, 116-133.

Smith, K., \& Ward, R. (1998). Floods: Physical Processes and Human Impacts (337 p). New York: John Wiley. 